\title{
Ankylosing spondylitis in monozygotic twins: studies on immunological parameters
}

\author{
Thomas Höhler, Rosula Hug, Peter M Schneider, Frank Krummenauer, \\ Christel Gripenberg-Lerche, Kaisa Granfors, Elisabeth Märker-Hermann
}

Medical Department of Internal Medicine, Johannes Gutenberg Universität Mainz, Mainz, Germany

T Höhler

R Hug

E Märker-Hermann

Institute of Legal

Medicine, Mainz,

Germany

P M Schneider

Institute of Medical

Statistics and

Documentation,

Mainz, Germany

F Krummenauer

National Public Health Institute, Department in Turku, Turku,

Finland

C Gripenberg-Lerche

K Granfors

Correspondence to: Dr T Höhler, I Medizinische Klinik und Poliklinik, Johannes

Gutenberg-Universität

Mainz, Langenbeckstr 1,

55101 Mainz, Germany.

Accepted for publication 9 March 1999

\begin{abstract}
Objective-To examine immunological parameters that might explain disease discordance in monozygotic twin pairs with ankylosing spondylitis (AS).

Methods-11 monozygotic twin pairs (nine with AS, two with undifferentiated spondyloarthropathy) were investigated. The peripheral $T$ cell receptor $V \beta$ repertoire was investigated using FACS analysis and 14 different $V \beta$ antibodies. In addition serum samples were tested for antibodies to Klebsiella pneumoniae, Streptococcus pyogenes, Candida albicans, Proteus mirabilis, and Escherichia coli. Peripheral blood lymphocyte reactivity against a number of bacteria was investigated by interferon $\gamma$ ELISPOT assays.

Results-Twins suffering from AS showed cellular hyporeactivity against $\mathrm{K}$ pneumoniae, $S$ pyogenes, $C$ albicans in the ELISPOT assays compared with healthy twins. In contrast with the antibody data, where no significant differences were observed between the two groups, AS concordant twins showed the most pronounced differences in their $V \beta$ repertoire on $\mathrm{CD} 4+$ and CD8+ lymphocytes.

Conclusions-Cellular hyporeactivity of peripheral blood cells to bacterial antigens might reflect defective $T$ cell responses allowing bacterial antigens to persist in diseased patients. There are probably other environmental factors that influence disease concordance. (Ann Rheum Dis 1999;58:435-440)
\end{abstract}

Ankylosing spondylitis (AS) and the other seronegative spondyloarthropathies are thought to be caused by inherited and environmental factors. Monozygotic (MZ) twins provide the unique opportunity to dissect this complex interaction. Data from a recent twin study have suggested that the development of AS is largely determined by genetic factors. ${ }^{1}$ Although more than $90 \%$ of AS patients carry the HLA-B27 gene, the contribution of this class I antigen to the overall disease risk is estimated to be only about $20-50 \%$. Concordance rates among $\mathrm{MZ}$ twins with $\mathrm{AS}$ range between $50 \%-75 \%$ compared with $10 \%-15 \%$ among dizygotic (DZ) twins. ${ }^{12}$ A ratio of $\mathrm{MZ}$ twin concordance: DZ twin concordance greater than 4:1 is typical for multigenic traits. Thus it is believed that other genetic factors than HLA-B27 are involved in the pathogenesis of the disease.
However, despite the strong genetic predisposition $30-50 \%$ of monozygotic twin pairs remain discordant for AS. A number of somatic developmental events are known to modify the identical genetic background ${ }^{3}$ and to cause disease discordance. Rearrangements in the genes for immunoglobulin and $\mathrm{T}$ cell receptor loci during differentiation of the immune system constitute an important source of such differences. Other somatic factors that influence disease expression are the random inactivation of the X-chromosome and DNA methylation, which is very important in silencing certain genes. ${ }^{3}$

Several lines of evidence emphasise the importance of environmental factors and especially bacterial infections in the initiation of AS. Data from patients with reactive arthritis and observations from AS patients suggest that infections with enterobacteria can trigger the onset of the disease. ${ }^{4}$ In patients with active AS Klebsiella pneumoniae could be isolated from the stool $^{5}$ and increased titres of anti-K pneumoniae IgA antibodies were detected in the serum samples of patients. ${ }^{67}$ In addition, subclinical inflammation of the terminal ileum was observed in a large proportion of AS patients. ${ }^{8}$

In this study we have investigated concordant and discordant $M Z$ twins for differences in their peripheral $\mathrm{T}$ cell $\mathrm{V} \beta$ repertoire. Furthermore, we have tested the serum for a set of antibodies against $K$ pneumoniae, Proteus mirabilis, and Escherichia coli and investigated whether in peripheral blood lymphocytes (PBL) there were differences in cellular reactivity against a panel of bacterial antigens.

\section{Methods}

PATIENTS

MZ twins were sought by advertisement in the newsletter of the German Ankylosing Spondylitis Society ("Bechterew Brief"). A total of 11 $M Z$ twin pairs responded and were invited for examination. All twins were seen and examined by the authors (TH and E M-H). Diagnosis was established according to the modified New York criteria ${ }^{9}$ by interview, physical examination, review of hospital records, and radiographs of the spine and sacroiliac joints. Four twins were concordant and five discordant for AS whereas in the other two twins one co-twin was affected by undifferentiated spondyloarthropathy (uSpA, patients 9.1 and 10.1 had both bilateral grade II sacroiliitis with clinical and radiological signs of spine involvement). Two healthy twin pairs unaffected by AS were used as controls (28 and 32 years old, respectively) in the investigations of the periph- 
Table 1 Clinical and HLA data of the investigated twin pairs. Patients with episodes of uveitis ( ${ }^{\star}$ ) or peripheral arthritis $(t)$ are indicated

\begin{tabular}{|c|c|c|c|c|c|c|c|c|}
\hline Concordant twins & & & Date of birth & Onset & $H L A-A$ & $H L A-B$ & $H L A-C$ & $H L A-D R$ \\
\hline 1.1 & male & AS & 1964 & 1993 & 2 & 27,62 & w2, w3 & 4,13 \\
\hline 1.2 & male & AS & 1964 & 1990 & 2 & 27,62 & w2, w3 & 4,13 \\
\hline $2.1 \dagger$ & male & AS & 1943 & 1966 & 31,32 & 13,27 & w2, w6 & 7,15 \\
\hline 2.2 & male & AS & 1943 & 1969 & 31,32 & 13,27 & $\mathrm{w} 2, \mathrm{w} 6$ & 7,15 \\
\hline $3.1^{\star} \dagger$ & male & AS & 1927 & 1944 & 2,11 & 27,62 & $\mathrm{w} 1, \mathrm{w} 2$ & 4,9 \\
\hline $3.2^{\star} \dagger$ & male & AS & 1927 & 1947 & 2,11 & 27,62 & w1, w2 & 4,9 \\
\hline $4.1^{\star} \dagger$ & female & AS & 1949 & 1975 & 3 & 27 & $\mathrm{w} 1, \mathrm{w} 2$ & 11,13 \\
\hline 4.2 & female & AS & 1949 & 1978 & 3 & 27 & w1, w2 & 11,13 \\
\hline \multicolumn{9}{|l|}{ Discordant twins } \\
\hline 5.1 & female & AS & 1930 & 1952 & 3,28 & 7,27 & w1, w7 & 4,15 \\
\hline 5.2 & female & healthy & 1930 & & 3,28 & 7,27 & w1, w7 & 4,15 \\
\hline 6.1 & male & AS & 1952 & 1975 & 2,29 & 27,44 & w2 & 4,16 \\
\hline 6.2 & male & healthy & 1952 & & 2,29 & 27,44 & w2 & 4,16 \\
\hline $7.1 \dagger$ & male & AS & 1942 & 1976 & 2,26 & 27,44 & w2, w3 & 11,15 \\
\hline $7.2^{\circ}$ & male & healthy & 1942 & & 2,26 & 27,44 & w2, w3 & 11,15 \\
\hline $8.1 \dagger$ & female & AS & 1947 & 1980 & 3 & 13,44 & w5, w6 & 1,3 \\
\hline 8.2 & female & healthy & 1947 & & 3 & 13,44 & w5, w6 & 1,3 \\
\hline 9.1 & female & USpA & 1930 & 1969 & 1,2 & 8,27 & w2, w7 & 1,7 \\
\hline 9.2 & female & healthy & 1930 & & 1,2 & 8,27 & w2, w7 & 1,7 \\
\hline 10.1 & female & USpA & 1964 & 1991 & 2 & 27,35 & $\mathrm{w} 2, \mathrm{w} 4$ & 4,16 \\
\hline 10.2 & female & healthy & 1964 & & 2 & 27,35 & $\mathrm{w} 2, \mathrm{w} 4$ & 4,16 \\
\hline 11.1 & female & AS & 1959 & 1976 & 2 & 51 & w7 & 11,13 \\
\hline 11.2 & female & healthy & 1959 & & 2 & 51 & w7 & 11,13 \\
\hline \multicolumn{9}{|l|}{ Healthy twins } \\
\hline 12.1 & female & healthy & 1969 & & 11,26 & 8,55 & w3, w7 & 3,13 \\
\hline 12.2 & female & healthy & 1969 & & 11,26 & 8,55 & w3, w7 & 3,13 \\
\hline 13.1 & male & healthy & 1964 & & 2,25 & 44,62 & w3, w5 & 1,4 \\
\hline 13.2 & male & healthy & 1964 & & 2,25 & 44,62 & w3, w5 & 1,4 \\
\hline
\end{tabular}

eral V $\beta$ T cell repertoire. $\mathrm{C}$ reactive protein (CRP) and erythrocyte sedimentation rate (ESR) were determined in each twin when blood samples were taken. None of the twins had an increased ESR or CRP, nor did any of the patients take immunosuppressive drugs or sulphasalazine. Table 1 gives details of patient characteristics. All patients gave informed consent for the subsequent investigations.

Blood samples were obtained from all twins. DNA was isolated by standard procedures. Monozygosity was determined by DNA fingerprinting analysis using the MZ1.3 multilocus probe as described in. ${ }^{10}$ In addition, analysis of HLA-A, -B and -C antigens was performed in every patient on PBL by the standard microlymphocytotoxicity method. ${ }^{11}$ DRB1 DNA typing was performed by nested PCR amplification using sequence specific primers. ${ }^{12}$

ANALYSIS OF TCR REPERTOIRE BY V $\beta$ SEGMENT SPECIFIC MONOCLONAL ANTIBODIES

PBL were isolated from $40 \mathrm{ml}$ heparinised whole blood by standard Ficoll gradient centrifugation. Lymphocytes were washed twice with washing medium (RPMI 1640 supplemented with $5 \%$ fetal calf serum (FCS), 100 $\mathrm{IU} / \mathrm{ml}$ penicillin, $100 \mu \mathrm{g} / \mathrm{ml}$ streptomycin) and cryopreserved in FCS (Biochrom, Berlin, Germany) with $10 \%$ dimethylsulphoxide in liquid nitrogen until analysis.

TCR-V $\beta$ chain phenotype was ascertained by specific labelling of $\mathrm{CD}^{+} \mathrm{T}$ lymphocytes with monoclonal antibodies (CoulterImmunotech, Hamburg, Germany) specific for 14 different TCR-V $\beta$ chains, $\mathrm{V} \beta 2$, V $\beta 3, \mathrm{~V} \beta 5.2$, $\mathrm{V} \beta 6.1, \mathrm{~V} \beta 8, \mathrm{~V} \beta 11, \mathrm{~V} \beta 12, \mathrm{~V} \beta 13.6, \mathrm{~V} \beta 14, \mathrm{~V} \beta 16$, $V \beta 17, V \beta 20, V \beta 21.3$ or $V \beta 22$. Percentages of respective TCR-V $\beta$ specificities of $\mathrm{CD}^{+}$lymphocytes were determined with a flow cytometer (FACScan, Becton Dickinson, Heidelberg, Germany) by evaluating $10000 \mathrm{CD}^{+}$ cells for each V $\beta$ specificity. CD $3+\mathrm{T}$ cells were analysed for the simultaneous expression of a specific V $\beta$ chain and CD4 or CD8.

ELISPOT ANALYSIS TO ENUMERATE THE PRECURSOR FREQUENCIES OF BACTERIA RESPONSIVE PBL

To analyse the frequency of lymphocytes specific for bacterial antigens in the peripheral blood the ELISPOT technique was used as described with some modifications. ${ }^{13}{ }^{14}$ Ninety six well microtitre plates with hydrophobic PVDF membrane bottoms (Millipore Multiscreen IP, Eschborn, Germany) were coated overnight with $100 \mu 1 /$ well of a solution with 10 $\mu \mathrm{g} / \mathrm{ml}$ of a monoclonal antibody to human interferon $\gamma$ (IFN $\gamma$ ) (Hölzel Diagnostik, Cologne, Germany) in PBS. The plates were washed four times with PBS. Triplicates of PBL $\left(2 \times 10^{5}\right.$ cells $)$ in RPMI 1640 medium supplemented with $10 \%$ heat inactivated human serum were added to the wells. Bacterial antigens were prepared and tested for optimal final concentrations in assay medium (RPMI$1640 / 10 \%$ HUS) to induce proliferative responses in PBMC bulk proliferation assays as described earlier. ${ }^{15}{ }^{16} \mathrm{~K}$ pneumoniae was chosen, as this pathogen has been discussed to be causally involved in the triggering of AS manifestation or AS flares. ${ }^{5}$ As control antigens, $E$ coli was used as an enterobacterial control and $S$ pyogenes and $C$ albicans as other microbial recall antigens.

Positive controls were supplemented with phytohaemagglutinin (PHA, $0.5 \mu \mathrm{g} / \mathrm{ml}$ ), negative controls with medium. After incubation for 48 hours at $37^{\circ} \mathrm{C}$ and $5 \%$ carbon dioxide the plates were washed four times with PBS containing $0.05 \%$ Tween. Subsequently the plates were incubated with a biotin labelled anti-IFN $\gamma$ monoclonal antibody at a concentration of $6 \mu \mathrm{g} / \mathrm{ml}$ in PBS supplemented with $0.5 \%$ of bovine serum albumin (BSA) for two hours at $37^{\circ} \mathrm{C}$ and washed again four times with PBS containing $0.05 \%$ Tween. Detection 


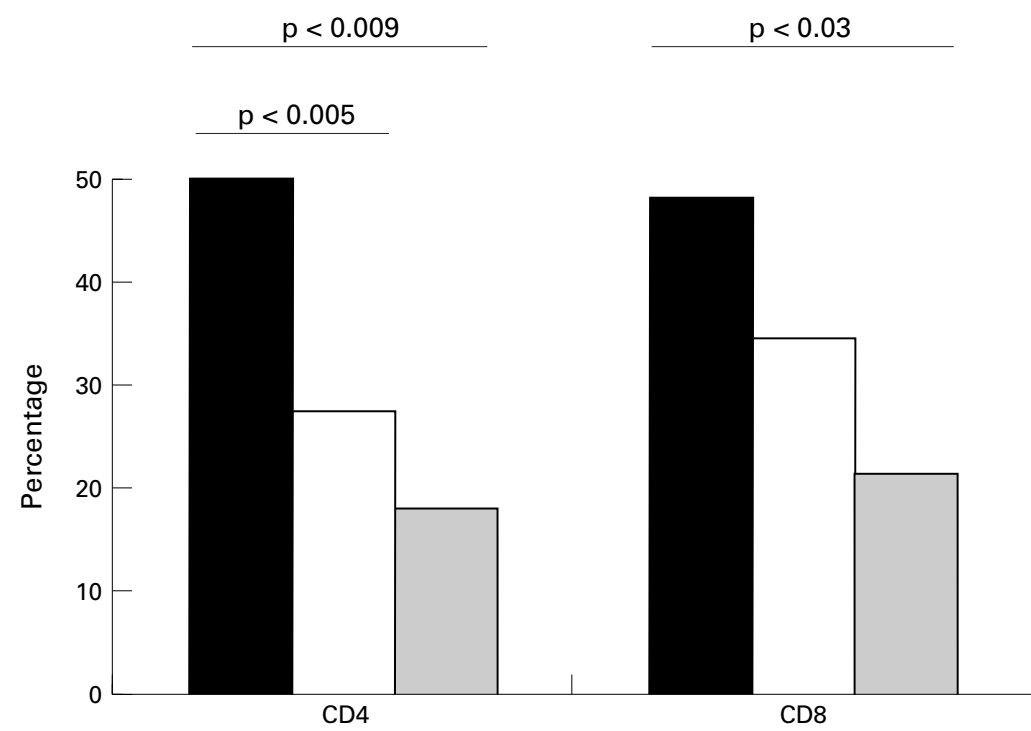

Figure 1 Differences in V $\beta$ repertoire in CD4+ and CD8+T lymphocytes in the different study groups. Concordant twin pairs are shown in black, discordant twins in white and the healthy twins in grey. The $y$ axis gives the percentage of significant differences in the V $\beta$ repertoire in relation to the number of comparisions made. Significant differences were observed in 28 of 56 comparisons (50\%) for CD4+ T cells in concordant twins (4 concordant twin pairs, 14 V $\beta$ families tested) compared with 27 of 98 comparisons (27.5\%) between discordant twins (7 discordant twin pairs, 14 V $\beta$ families tested; $p<0.005)$.

was carried out using the Vectastain Elite ABC Kit (Vector Laboratories, Burlingame, California, USA). Spots were automatically enumerated using an electronic computer assisted imaging system (Leitz, Wetzlar, Germany). ${ }^{14}$ In addition, the results were checked by eye using a dissection stereomicroscope (Zeiss SV-6, Oberkochen, Germany). All results were expressed as means of triplicates from numbers of spot forming cells (SFC) per $2 \times 10^{5} \mathrm{PBL}$ after deduction of medium results.

ELISAS FOR BACTERIA SPECIFIC ANTIBODIES IN THE SERUM

Sodium dodecyl sulphate (SDS) extracts of $K$ pneumoniae strains 21, 43, and ATCC 27736, E coli, and $P$ mirabilis were prepared as previously described. ${ }^{7} \operatorname{IgM}, \operatorname{IgG}$, and IgA class antibodies were measured as described earlier. ${ }^{7}$ The polystyrene microtitre plate (Nunc, Roskilde, Denmark) were coated with SDS extracts of $K$ pneumoniae, $E$ coli or $P$ mirabilis $(5 \mu \mathrm{g} / \mathrm{ml})$ in PBS $(0.1 \mathrm{~mol} / \mathrm{l}, \mathrm{pH} 7.5 ; 100 \mu \mathrm{l} /$ well $)$ overnight at $37^{\circ} \mathrm{C}$. The plates were saturated with $1 \%$ BSA in PBS $(100 \mu 1 /$ well). Patients serum samples at 1:250 (IgM, IgA) or 1:300 (IgG) dilution $(75 \mu \mathrm{l} /$ well) were incubated on the plates for two hours at $37^{\circ} \mathrm{C}$. Thereafter, 75 $\mu \mathrm{l} /$ well of alkaline phosphatase conjugated swine antihuman IgM, IgA or IgG (Orion Diagnostica, Espoo, Finland) diluted 1:250, $1: 250,1: 500$, respectively were incubated on the plates overnight at room temperature. Fresh $p$-nitrophenyl phosphate in diethanolamine- $\mathrm{MgCl}_{2}$-buffer solution $(1 \mathrm{mg}$ / $\mathrm{ml}$; Orion Diagnostica) was added, incubated for 30 minutes at $37^{\circ} \mathrm{C}$ and the reaction stopped with $1 \mathrm{M}$ sodium hydroxide. The optical density was measured with Titertek Multiscan Photometer (Labsystems, Helsinki, Finland) at wavelength of $405 \mathrm{~nm}$.

Antibody concentrations are expressed as enzyme immunoassays units (EIU): 1 EIU is
$1 / 100$ of the corresponding antibody concentration in the positive reference serum.

STATISTICAL ANALYSIS

To obtain quantitative information on differences between discordant and concordant sib pairs, we performed exploratory comparisons both within sib pairs and among sib pairs for each of the V $\beta$ expressions, ELISPOT, and antibody ELISA data by one sample Wilcoxon tests.

For each of the $\mathrm{V} \beta$ antigens these tests were based on the relative difference in $\mathrm{V} \beta$ measurements, where the difference was computed for each of the sib pairs, respectively.

To account for possibly extreme discordance the corresponding one sample Wilcoxon tests were additionally based on the absolute difference of measurements within each sib pair.

For each of the V $\beta$ measurements the difference in one sib pair was compared with the corresponding differences among the subgroup of the remaining sib pairs via one sample Wilcoxon tests (subgroups were the two healthy twin pairs, seven discordant, and the four AS concordant twin pairs). For each V $\beta$ measurement a sib pair was regarded significant from the others as soon as its corresponding "single Wilcoxon" $p$ value turned out less than 0.05 ; the number of significant tests was then related to the overall number of tests performed in this setting. The resulting rates were then compared by $\chi^{2}$ tests.

All computations were performed using standard procedures in SAS (Release 6.10).

\section{Results}

Table 1 shows patient characteristics. Our study group comprised of six female and five male twin pairs. Nine twin pairs suffered from AS whereas in two female pairs disease had to be classified as uSpA. The mean age of the 11 twin pairs was 49.1 years. All but one discordant twin pair were well beyond the typical age of onset between 20 and 30 years. The overall concordance rate for AS was $44.4 \%$. Interestingly concordance rates varied according to sex. Among the four female twin pairs with AS it was only $25 \%$ whereas in the five male twin pairs $60 \%$ were concordant for the disease. However the number of investigated twin pairs was too small to reach statistical significance. A previous study had suggested that B60 or DR1 influence the concordance rate among dizygotic twins. ${ }^{1}$ Interestingly B60 was not observed at all in our study. DR1 was present in two female twins discordant for AS. Fifty per cent of the concordant twins were also concordant for extraspinal disease manifestations (uveitis, peripheral arthritis, entheseopathy).

\section{V $\beta$ REPERTOIRE OF PERIPHERAL T CELLS}

None of the investigated V $\beta$ families showed a significant variation in association with the disease status of the twins. The four concordant twin pairs showed the strongest discordance in the V $\beta$ use in PBL. Significant differences occurred in 27 of 56 comparisons $(48.2 \%)$ made for CD8+ $(\mathrm{p}<0.03$ compared with healthy twins) and in 28 of 56 comparisons for 


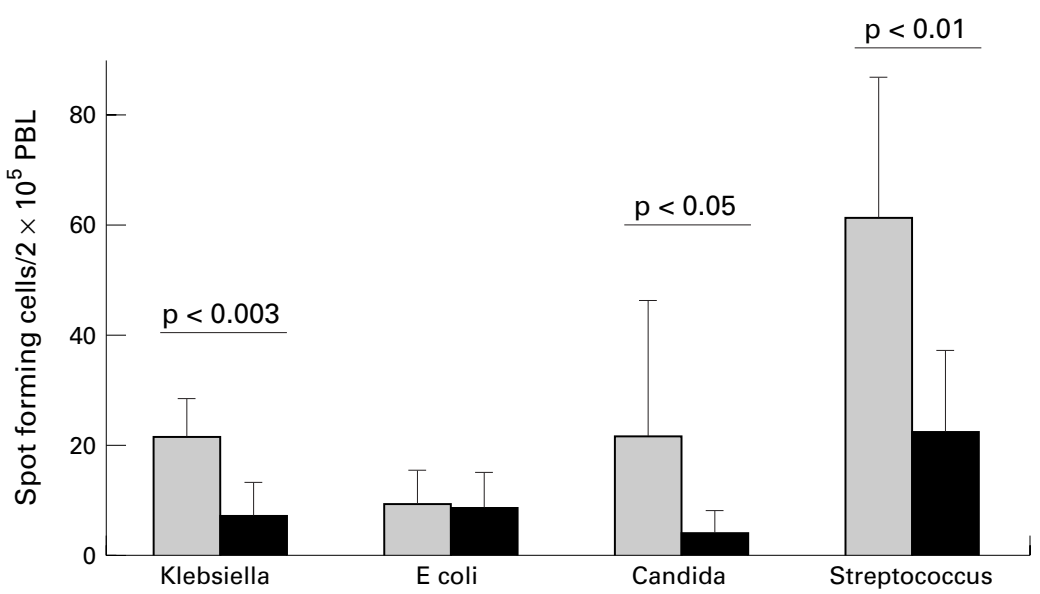

Figure 2 Results of the IFN $\gamma$ ELISPOT assays. Twins with AS and $u S p A$ are shown in black, unaffected co-twins in grey.

CD4+ $T$ cells $(p<0.005$ compared with discordant twins, $\mathrm{p}<0.009$ compared with healthy twins). In the discordant twins significant differences were observed in $27.5 \%$ (27 of 98) of the comparisons for $\mathrm{CD} 4+$ and in $34.7 \%$ (34 of 98) of the comparisons for CD8+ $\mathrm{T}$ cells compared with $17.9 \%$ (5 of 28 ) and $21.4 \%$ (6 of 28 ) in the two healthy twin pairs (fig 1).

\section{ELISPOT ANALYSIS}

Figure 2 shows the results of ELISPOT assays. $\mathrm{PBL}$ producing IFN $\gamma$ in response to $K$ pneumoniae (mean 21.6 cells, 95\% confidence intervals $14.5,28.7$; v 7.2 cells, $95 \%$ CI 3.5, $11.1 ; \mathrm{p}<0.003$ ), $S$ pyogenes (mean $61.2,95 \% \mathrm{CI}$ $32.9,89.6$; v 22.2, 95\% CI 13.1, 31.3; $\mathrm{p}<0.001$ ), and $C$ albicans (mean $21.7,95 \% \mathrm{CI}$ $4.3,84.2 ; v 4,95 \%$ CI $1.2,6.8 ; \mathrm{p}<0.05)$ were found in significantly higher frequencies in unaffected subjects than in twins with AS or $\mathrm{uSpA}$, respectively. No statistically significant differences were observed for $E$ coli.

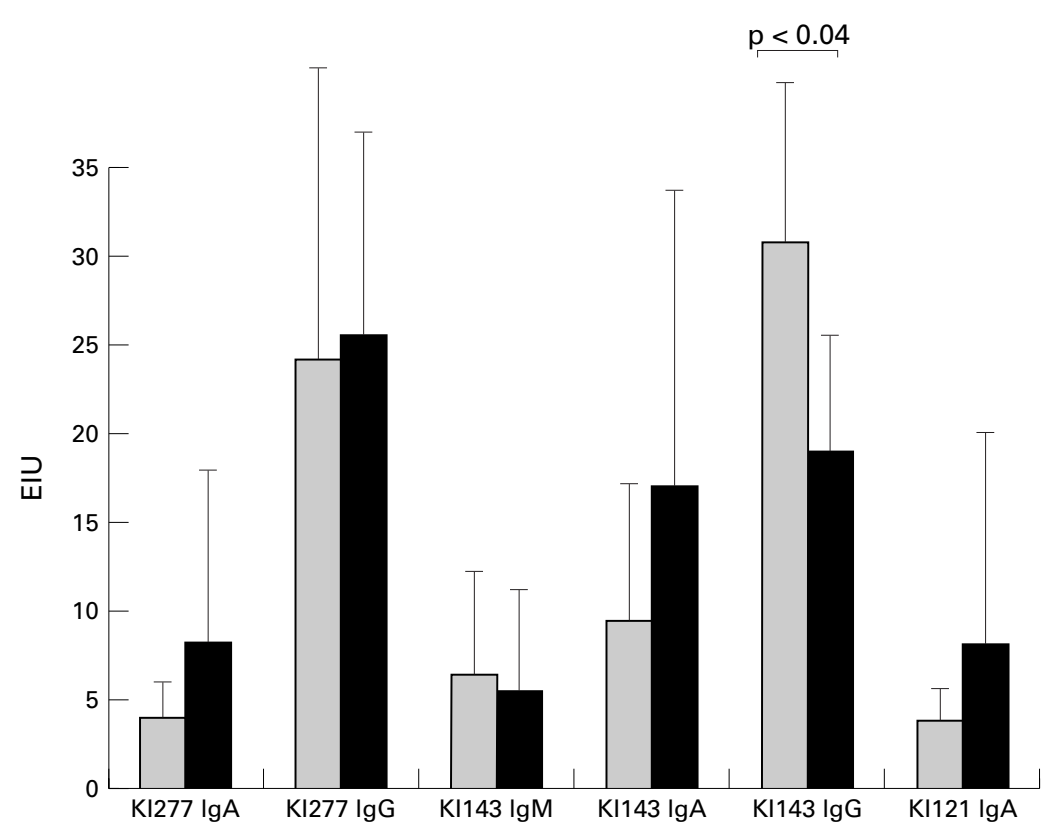

Figure 3 Titres of selected anti-klebsiella antibodies in the serum samples of the patients. Twins with $A S$ and $u S p A$ are shown in black, unaffected co-twins in grey.
BACTERIAL ANTIBODIES

The only significant difference detected among the panel of antibacterial antibodies was for the $K$ pneumoniae $143 \mathrm{IgG}$ antibody, which was found with significant higher titres in unaffected twin pairs (30.8 EIU, 95\% CI 18.9, 42.7; $v 19$ EIU, 95\% CI 15.1, 22.8; p<0.04). Titres for K pneumoniae IgA antibodies were in general higher in diseased twins, but the differences did not reach even local statistical significance (see fig 3).

\section{Discussion}

We have studied genetic and environmental factors that have previously been shown to be related to the development of AS in a group of $\mathrm{MZ}$ twins with AS and uSpA. In contrast with recent studies ${ }^{12}$ the overall concordance rate in our study for AS was only $44 \%$. This number differed between male and female twins. In $60 \%$ of the male twins both were affected by AS compared with only $25 \%$ of the female twins. Although AS is a disease that predominantly affects men, women constitute $20 \%$ $40 \%$ of AS patients. If these findings could be confirmed in a larger series of twins they would suggest that female sex could have a protective effect against the development of AS.

$\mathrm{T}$ lymphocytes are thought to be the most important players in the immunopathogenesis of AS. ${ }^{4}$ Synovial fluid derived CD4+ and CD8+ clones recognising enterobacterial and self antigens in patients with AS have been identified. ${ }^{15}{ }^{17}$ Analyses of the TCR V $\beta$ use of HLA-B27 restricted bacteria specific and autoreactive CD8+ T-cell clones showed the preferential rearrangement of three closely related V $\beta$ families (TCR V $\beta 13,14,17){ }^{18}$ Gene rearrangements at the $T$ cell receptor loci constitute an important somatic event that could modify a person's susceptibility to autoimmune disease. ${ }^{3}$ The peripheral $\mathrm{T}$ cell repertoire is shaped by positive and negative selection directed by self major histocompatibility complex bearing cells in the thymus. Previous studies have shown that $M Z$ twins are very similar in their peripheral TCRV $\beta$ repertoire, even if analyses were performed at different time points. ${ }^{1920}$ Similar results were obtained for the two healthy concordant twin pairs in our study (fig 1). The most pronounced differences in the TCRV $\beta$ repertoire were present among the AS concordant twins in CD4+ cells and to a smaller degree for $\mathrm{CD} 8+\mathrm{T}$ cells resulting in significant differences for the comparison of discordant with healthy twin pairs. Significant differences in the TCR V $\beta$ use were also more frequent in AS discordant twin pairs compared with the healthy twins but did not reach statistical significance. These results suggest that the observed differences are most probably caused by the ongoing inflammatory process by continuous stimulation of $\mathrm{T}$ cells bearing different $\mathrm{V}-\beta$ families. This is supported by our own observations. Molecular analysis of the T cell receptor variability of peripheral $\mathrm{T}$ cells by complementarity determining region 3 assays in the investigated twin pairs has shown that clonal expansions of CD4+ and CD8+ T cells 
accounted for most of the differences observed and were much more common when both twins where suffering from $\mathrm{AS}^{21}$

It is believed that enterobacterias, and namely $K$ pneumoniae can trigger AS. In patients developing AS, both $\mathrm{T}$ cell and humoral immune responses to $K$ pneumoniae differ from those seen in healthy people. It has been shown that anti- $K$ pneumoniae $\operatorname{IgA} 1$ and $\operatorname{IgA} 2$ antibodies are found with increased titres in patients with AS both with and without peripheral joint disease. ${ }^{67}$ Although twins suffering from AS in general showed higher anti- $K$ pneumoniae IgA titres differences did not reached statistical significance possibly because of the small number of people tested. The only significant difference was observed for K pneumoniae $\mathrm{K} 1143 \mathrm{IgG}$ antibodies, which were increased in the healthy co-twins. However, it has to be kept in mind that 18 different antibodies were tested and that borderline significant results can arise by chance.

A quantitative reduction of $K$ pneumoniae responsive $\mathrm{T}$ cells in the peripheral blood of AS patients compared with healthy controls has been reported earlier by our group. ${ }^{15}$ However, it is unclear whether this reflects the ongoing disease process or a defective cellular defence against $K$ pneumoniae secondary to HLA-B27 or other genes as suggested in several studies. ${ }^{223}$ Our results from ELISPOT assays, which have been shown to be a reliable technique to enumerate the number of antigen specific $\mathrm{T}$ cells in the peripheral blood ${ }^{14}$ show that there are significantly less IFN $\gamma$ secreting cells in response not only to $K$ pneumoniae antigens but also to $S$ pyogenes and $C$ albicans antigens in twins with AS and uSpA compared with their unaffected twin partners. IFN $\gamma$ is mainly secreted by $\mathrm{T}$ lymphocytes and to a lesser extend by natural killer cells upon stimulation. Interestingly infections with streptococci are known to trigger guttate psoriasis. The lowest reactivity towards streptococci was observed in patient 7.1 , who was also suffering from psoriasis. No differences were found for $E$ coli extracts.

In all twins antibody and ELISPOT tests were positive but there were notable differences in their individual responses. PBL of diseased twins did not not only contain less klebsiella specific IFN $\gamma$ secreting $\mathrm{T}$ cells than those of their healthy twin partner, a comparable reduction was also observed for candida and $S$ pyogenes specific responses. These findings do not strengthen the hypothesis of an involvement of a triggering klebsiella infection followed by sequestration of klebsiella specific $T$ cells at the site of inflammation. Instead they point to a more generalised immunological hyporesponsiveness in $\mathrm{SpA}$ patients including other common bacterial and fungal antigens. A primarily defective first line of defence against these bacteria seems to be an unlikely explanation as the genetically identical co-twins showed normal reactivity. Another possibility is that specific cells could have been rendered anergic because of incomplete stimulation by antigen presenting cells. Defective presentation of bacterial antigens could be another reason for hyporeactivity. It has recently been shown that phagocytosis of $Y$ enterocolitica by HLA$\mathrm{B} 27+$ monocytes reduces the expression of HLA-B27 epitopes that are important for $\mathrm{T}$ cell recognition. ${ }^{25}$ Crossover experiments by stimulating the $\mathrm{T}$ lymphocytes of the affected twin with antigen presenting cells from the healthy co-twin could help to understand this phenomenon.

The results of our twin study suggest that there have to be a number of factors protecting discordant $M Z$ twins from the development of AS. In our investigation female sex seemed to have a strong protective effect. If we accept that enterobacterias like $K$ pneumoniae are involved in the pathogenesis of AS, we are faced with the phenomenon that all twins in our study were positive for klebsiella antibodies or in the ELISPOTS but reponded differently by means of antibody and $\mathrm{T}$ cell reactivity. Elucidating the mechanisms that cause the differences in reactivity to these bacterias that have to be other than genetic, might help us to understand the environmental conditions that favour disease expression.

Funding: this project was supported by a grant from the Deutsche Forschungsgemeinschaft, SFB 311, A12 and the European Commission Biomed 2 Programme.

We are grateful to Dr Claudius U Meyer for his excellent technical assistance performing the FACS analysis of PBL. We also would like to thank Tiina Lähde, Petra Everke, and Jutta Lummer for their technical support.

1 Brown MA, Kennedy LG, MacGregor AJ, Darke C, Duncan E, Shatford JL, et al. Susceptibility to ankylosing Duncan E, Shatford JL, et al. Susceptibility to ankylosing

2 Järvinen P. Occurence of ankylosing spondylitis in a nationwide series of twins. Arthritis Rheum 1995;38:381-3.

3 Gregersen PK. Discordance for autoimmunity in monozygotic twins. Are identical twins really identical. Arthritis Rheum 1993;36:1185-92.

4 Sieper J, Braun J. Pathogenesis of spondyloarthropathies. Persistent bacterial antigen, autoimmunity, or both? Arthritis Rheum 1995;35:1547-53.

5 Ebringer RW, Cawdell DR, Cowling P, Ebringer A. Sequential studies in ankylosing spondylitis: association of Klebsiella pneumoniae with active disease. Ann Rheum Dis 1978;37:146-51.

6 Mäki-Ikola O, Lehtinen K, Granfors K, Vainionpää R, Toivanen P. Bacterial antibodies in ankylosing spondylitis. Clin Exp Immunol 1991;84:472-5.

7 Mäki-Ikola O, Nissilä M, Lehtinen K, Leirisalo-Repo M, Mäki-Ikola O, Nissilä M, Lehtinen K, Leirisalo-Repo M,
Toivanen P, Granfors K. Antibodies to Klebsiella pneumoniae, Escherichia coli, and Proteus mirabilis in the sera of patients with axial and peripheral form of ankylosing spondylitis. Br J Rheomatol 1995;34:413-17.

8 Mielants H, Veys EM. The gut in the spondyloarthropathies. J Rheumatol 1990;17:7-10.

9 Van der Linden S, Valkenburg HA, Cats A. Evalution of diagnostic criteria for ankylosing spondylitis: a proposal for modification of the New York criteria. Arthritis Rheum 1984;27:361-8.

10 Schacker U, Schneider PM, Holtkamp B, Bohnke E, Fimmers R, Sonneborn HH, et al. Isolation of the DNA minisatellite probe MZ1.3 and its application to DNA 'fingerprinting' analysis. Forensic Sci Int 1990;44:209-14.

11 Terasaki PI, Bernoco D, Park MS, Ozturk G, Iwaki Y. Mikrodroplet testing for HLA-A, -B, -C and -D antigens. Mikrodroplet testing for HLA-A,

12 Bein G, Gläser R, Kirchner H. Rapid HLA-DRB1 genotyping by nested PCR amplification. Tissue Antigens 1992;39: 68-73.

13 Czerkinsky C, Nilsson LA, Nygren H, Ouchterlony Ö, Tarkowsky A. A solid-phase enzyme linked immunospo (ELISPOT) assay for enumeration of specific antibody secreting cells. J Immunol Methods 1983;65:109-15.

14 Herr W, Schneider J, Lohse AW, Meyer zum Büschenfelde $\mathrm{KH}$, Wölfel $\mathrm{T}$. Detection and quantification of blood derived CD8-positive Tlymphocytes secreting TNF in TNF in response to HLA A2.1-binding melanoma and viral antigens. J Immunol Methods 1996;191:131-42.

15 Hermann E, Sucké B, Droste U, Meyer zum Büschenfelde KH. Klebsiella pneumoniae reactive T cells in blood and synovial fluid of patients with ankylosing spondylitisComparison with HLA-B2 $7^{+}$healthy control subjects in limiting dilution study and determination of the specificity 
of synovial fluid T cell clones. Arthritis Rheum 1995;38: $1277-82$

16 Hermann E, Mayet W-J, Lohse AW, Grevenstein J, Meye zum Büschenfelde K-H, Fleischer B. Proliferative respons of synovial fluid and peripheral blood mononuclear cells to arthritogenic and non-arthritogenic microbial antigens an to the $65 \mathrm{kD}$ mycobacterial heat shock protein. Med Microbiol Immunol 1990;179:215-24.

17 Hermann E, Yu DTY, Meyer zum Büschenfelde K-H Fleischer B. HLA-B27-restricted CD8+ T cells derived from synovial fluids of patients with reactive arthritis and ankylosing spondylitis. Lancet 1993;342:646-50.

18 Duchmann R, May E, Ackermann B, Meyer zum Büschen, cyte KH, Mäker-Herted cytotoxic T lymphocyte responses to arthritogenic enterobacteria or self antigens are dominated by closely related 9 Davey MP, Meyer MM, Bakke AC. T cell receptor V $\beta$ gene 9 Davey MP, Meyer MM, Bakke AC. T cell receptor V $\beta$ gene expression.

20 Gulwani-Akolkar B, Posnett DN, Janson CH, Grunewald J, Wigzell H, Akolkar P, Gregersen PK, et al. T cell recepto $\mathrm{V}$-segment frequencies in peripheral blood $\mathrm{T}$ cells correlate with human leukocyte antigen type. J Exp Med 1991;174: 1139-46.

21 May E, Lambert C, Duchmann R, Höhler T, Meyer zum Büschenfelde KH, Märker-Hermann E. Selective expansions in peripheral blood CD4+ and CD $8+T$ cell subsets of patients with ankylosing spondylitis implicate responses to distinct antigens. A study in HLA-B27 monozygotic twins. Arthritis Rheum 1997;40 (suppl):S227.

22 Kapasi K, Inman RD. HLA-B27 expression modulates gram-negative bacterial invasion into transfected $\mathrm{L}$ cells. J Immunol 1992;148:3554-9.

23 Laitio P, Virtala M, Salmi M, Pelliniemi LJ, Yu DTY, Granfors K. HLA-B27 modulates intracellular survival of Salmonalla enteritidis in human monocytic cells. Eur J Immunol 1997;27:1331-8.

24 Hermann E, Fleischer B, Mayet W-J, Poralla T, Meyer zum Büschenfelde KH. Response of synovial fluid T cell clones to Yersinia enterocolitica antigens in patients with Yersinia arthritis. Clin Exp Immunol 1989;75:365-70.

25 Wuorela M, Jalkanen S, Kirveskari J, Laitio P, Granfors K. Yersinia enterocolitica serotype O:3 alters the expression of serologic HLA-B27 epitopes on human monocytes. Infect Immun 1997;165:2060-6. 